\title{
Article/Artigo
}

\section{Seroepidemiology of Trypanosoma cruzi infection in the semiarid rural zone of the State of Rio Grande do Norte, Brazil}

\author{
Soroepidemiologia da infecção pelo Trypanosoma cruzi na zona rural do semiárido do Estado \\ do Rio Grande do Norte, Brasil
}

\section{Carlos Ramon do Nascimento Brito ${ }^{1}$, George Harisson Felinto Sampaio ${ }^{2}$, Antonia Cláudia Jácome da Câmara ${ }^{3}$, Daniela Ferreira Nunes ${ }^{1}$, Paulo Roberto Medeiros de Azevedo ${ }^{4}$, Egler Chiari ${ }^{5}$ and Lúcia Maria da Cunha Galvão ${ }^{2}$}

\begin{abstract}
Introduction: A seroepidemiological survey was carried out to evaluate Trypanosoma cruzi infection in an endemic area of the State of Rio Grande do Norte, Brazil, involving rural residents. Methods: Sixteen municipalities were randomly selected, 15 from the west mesoregion and one from the central, with an estimated population of 83,852 individuals. A total of 1,950 blood samples were collected in the west mesoregion and 390 in Caicó. Anti-T. cruzi antibodies were detected using the Chagatest ${ }^{\circledR}$ ELISA HAI-hemagglutination kits and indirect immunofluorescence. As sera presented indeterminate results, TESAcruzi ${ }^{\circledR}$ western blot was performed to confirm reactivity. Results: An estimated seroprevalence of $6.5 \%$ was determined for the west mesoregion and 3.3\% for Caicó. Seropositivity rises progressively with the age of individuals, up to 40 years in Caicó and up to 50 years in the west mesoregion. Only educational level and knowledge regarding the triatomine were associated with seropositivity. No seroreactive individuals under 18 years of age were identified. Conclusions: Infection by T. cruzi remains high and is concentrated in municipalities in the central western area of the west mesoregion; however, evidence suggests a decline in vector transmission in this mesoregion and in Caicó. Epidemiological variables appear not to influence seropositivity, with the exception of education and knowledge concerning the triatomine, among seroreactive individuals from the west mesoregion.
\end{abstract}

Keywords: Trypanosoma cruzi. Chagas disease. Seroprevalence. Epidemiological variables.

\section{RESUMO}

Introdução: A infecção pelo Trypanosoma cruzi foi avaliada em uma área endêmica do Estado do Rio Grande do Norte, Brasil, por inquérito soroepidemiológico amostral em moradores da zona rural. Métodos: Dezesseis municípios foram sorteados, 15 da mesorregião oeste e um da central, com população estimada em 83.852 indivíduos. Foram coletadas 1.950 amostras de sangue no oeste e 390 em Caicó. A detecção de anticorpos anti-T. cruzi foi realizada usando os kits Chagatest ${ }^{\circledR}$ ELISA, HAI-hemaglutinação e a reação de imunofluorescência indireta. Nos soros com resultados indeterminados foi realizado o western blot TESAcruzi ${ }^{\circledR}$ para confirmação da reatividade. Resultados: A estimativa da soroprevalência revelou 6,5\% para a mesorregião oeste e 3,3\% em Caicó. A soropositividade eleva-se progressivamente com a idade dos indivíduos até a quinta década de vida em Caicó e na sexta década na mesorregião oeste. Apenas o grau de escolaridade e o conhecimento do triatomíneo evidenciaram associação à soropositividade. Não foram identificados indivíduos sororreativos com idade inferior a 18 anos. Conclusões: A infecção pelo T. cruzi persiste mais elevada e concentrada em municípios da área central da mesorregião oeste, mas evidências sugerem o declínio da transmissão vetorial nessa mesorregião e em Caicó As variáveis epidemiológicas parecem não exercer influência na soropositividade, à exceção da escolaridade e conhecimento do triatomíneo entre indivíduos sororreativos da mesorregião oeste.

Palavras-chaves: Trypanosoma cruzi. Doença de Chagas. Soroprevalência. Variáveis epidemiológicas.

1. Programa de Pós-Graduação em Ciências da Saúde, Centro de Ciências da Saúde, Universidade Federal do Rio Grande do Norte, Natal, RN. 2. Programa de Pós-Graduação em Ciências Farmacêuticas, Centro de Ciências da Saúde, Universidade Federal do Rio Grande do Norte, Natal, RN. 3. Departamento de Análises Clínicas e Toxicológicas, Centro de Ciências da Saúde, Universidade Federal do Rio Grande do Norte, Natal, RN. 4. Departamento de Estatística, Centro de Ciências Exatas e da Terra, Universidade Federal do Rio Grande do Norte, Natal, RN. 5. Departamento de Parasitologia, Instituto de Ciências Biológicas, Universidade Federal de Minas Gerais, Belo Horizonte, MG.

Address to: Dra. Lúcia Maria da Cunha Galvão. PPgCF/CCS/UFRN. Rua Gal. Gustavo Cordeiro de Farias s/n, Petrópolis, 59012-570 Natal, RN, Brasil.

Phone: 5584 3342-9827; 5584 3342-9824

e-mail: galvao@icb.ufmg.br; luciabhster@gmail.com

Received in 29/09/2011

Accepted in 20/12/2011

\section{INTRODUCTION}

More than a century after its discovery, Trypanosoma cruzi ${ }^{1}$ infection still represents a significant public health problem, with 7.7 million infected people in Latin America and more than 10,000 deaths in $2008^{2,3}$. The annual number of new cases of infection by vector transmission diminished from 700,000 in 1990 to 41,200 in 2006, and the number of deaths from Chagas disease decreased from approximately 50,000 per year in 1990 to 12,500 per year in $2006^{4}$.

In Brazil, the first national serological survey (1975-1980) estimated a prevalence of infection by $T$. cruzi of $4.2 \%$ in the general rural population ${ }^{5}$. In the Northeastern region, prevalence was $3.1 \%^{6}$, with the highest rates in the States of Sergipe (6\%) and Bahia (5.4\%) and lowest in Ceará (0.8\%) and Maranhão (0.1\%), while in the State of Rio Grande do Norte (RN), it was $1.8 \%^{5}$.

A second serological survey, conducted between 1989 and 1997 among schoolchildren 7 to 14 years of age, analyzed 226,138 samples in 842 municipalities in 18 states and found a positivity of $0.1 \%$. In the Northeastern region, the prevalence of T. cruzi infection was $0.9 \%$, with the highest prevalence of $0.2 \%$ for $\mathrm{RN}^{7}$.

The latest survey of seroprevalence for T. cruzi, conducted between 2001 and 2008 among 104,954 children up to five years of age in rural Brazil, except for the State of Rio de Janeiro, determined a positivity of $0.03 \%$. In $\mathrm{RN}$, among a total of 1,750 samples analyzed, one newborn child was identified as seropositive even though the mother was seronegative, indicating probable active vector transmission $^{8}$. The control of triatomines in the Northeastern region is a current and future problem. This region has a high concentration of Triatoma brasiliensis, and in Brazil, it is the center of vector dispersion that is reportedly difficult to control ${ }^{7,9,10}$. Moreover, it still possesses factors of concern, since the region remains socially depressed and has residences that may be suitable for triatomine 
colonization; it also presents a predominance of vectors that are difficult to control and a low level of operational coverage of the Chagas Disease Control Program (Programa de Controle da Doença de Chagas, PCDCh) $)^{6,11}$.

Considering that in $\mathrm{RN}$, the existence of autochthon species and T. cruzi transmitters has been proven, demonstrated by the constant presence of Tr. brasiliensis and Tr. pseudomaculata, together with the emergence of species like Panstrongylus lutzi, the probability of an individual being included in an area of transmission risk is reasonable. Following control programs directed toward the vector, no epidemiological data have been collected regarding the real situation of human infection by T. cruzi in the municipalities included in the endemic area for Chagas disease in this state. This study aimed to conduct a seroepidemiological survey to estimate the prevalence of infection among rural residents of municipalities in the west mesoregion and Caicó, and to evaluate possible factors associated with Chagas disease infection.

\section{METHODS}

\section{Area studied}

The State of Rio Grande do Norte ( $\mathrm{RN}$ ) is located in Northeastern Brazil between $4^{\circ} 49^{\prime} 53^{\prime \prime S}$ and $6^{\circ} 58^{\prime \prime} 57^{\prime \prime} S$, and $35^{\circ} 58^{\prime} 03^{\prime \prime} \mathrm{W}$ and $38^{\circ} 36^{\prime} 12^{\prime \prime} \mathrm{W}$. The population is 3,168,133 inhabitants, with 702,694 $(22.2 \%)$ living in rural areas ${ }^{12}$. The state has an area of $52,796.79 \mathrm{~km}^{2}$ (approx. 20,385 $\mathrm{mi}^{2}$ ) and is bordered to the north and the east by the Atlantic Ocean, to the south by the State of Paraiba, and to the west by the State of Ceará. Politically, it is divided into 167 municipalities grouped into four mesoregions: west, central, agreste, and east ${ }^{12,13}$

(Figure 1). The west mesoregion includes 62 municipalities and is the most populous and second most important from an economic viewpoint, while the central mesoregion consists of 37 municipalities and is less populated. The predominant vegetation is Brazilian savanna (Caatinga); neosol soil types are fairly frequent, with the constant appearance of stony and rocky surfaces, and outcrops of rocks are common.

\section{Sampling plan}

The design for sampling individuals was performed individually for each mesoregion involved. For the west mesoregion, this design was defined in two stages. First, the municipalities were classified into strata according to the rural population and using the cumulative square root of the frequency method. During this stage, three strata of municipalities were defined: those with less than 2,000 residents in rural areas, those having between 2,000 and 6,000 rural residents, and those with over 6,000 rural residents. For each of the strata, five municipalities were randomly selected, resulting in a total of 77,203 rural residents in 15 municipalities, using the census database of the Brazilian Institute of Geography and Statistics (Instituto Brasileiro de Geografia e Estatística - IBGE) ${ }^{14}$. From within the total sample, a simple random sampling was performed in the second stage. To calculate the sample size the variable $\mathrm{p}$ was considered, i.e., the proportion of subjects reactive for T. cruzi infection in the west mesoregion. Based on a previous study involving 515 rural residents in the municipality of Caraúbas in the west mesoregion ${ }^{15}$, a preliminary estimate of $\mathrm{p}=0.09$ was obtained.

For the municipality of Caico, the sample design for the serological survey was based on simple random sampling. To calculate the sample size the variable $\mathrm{p}$ was considered, i.e., the proportion of individuals with positive serology, which was $\mathrm{p}=0.037$, according

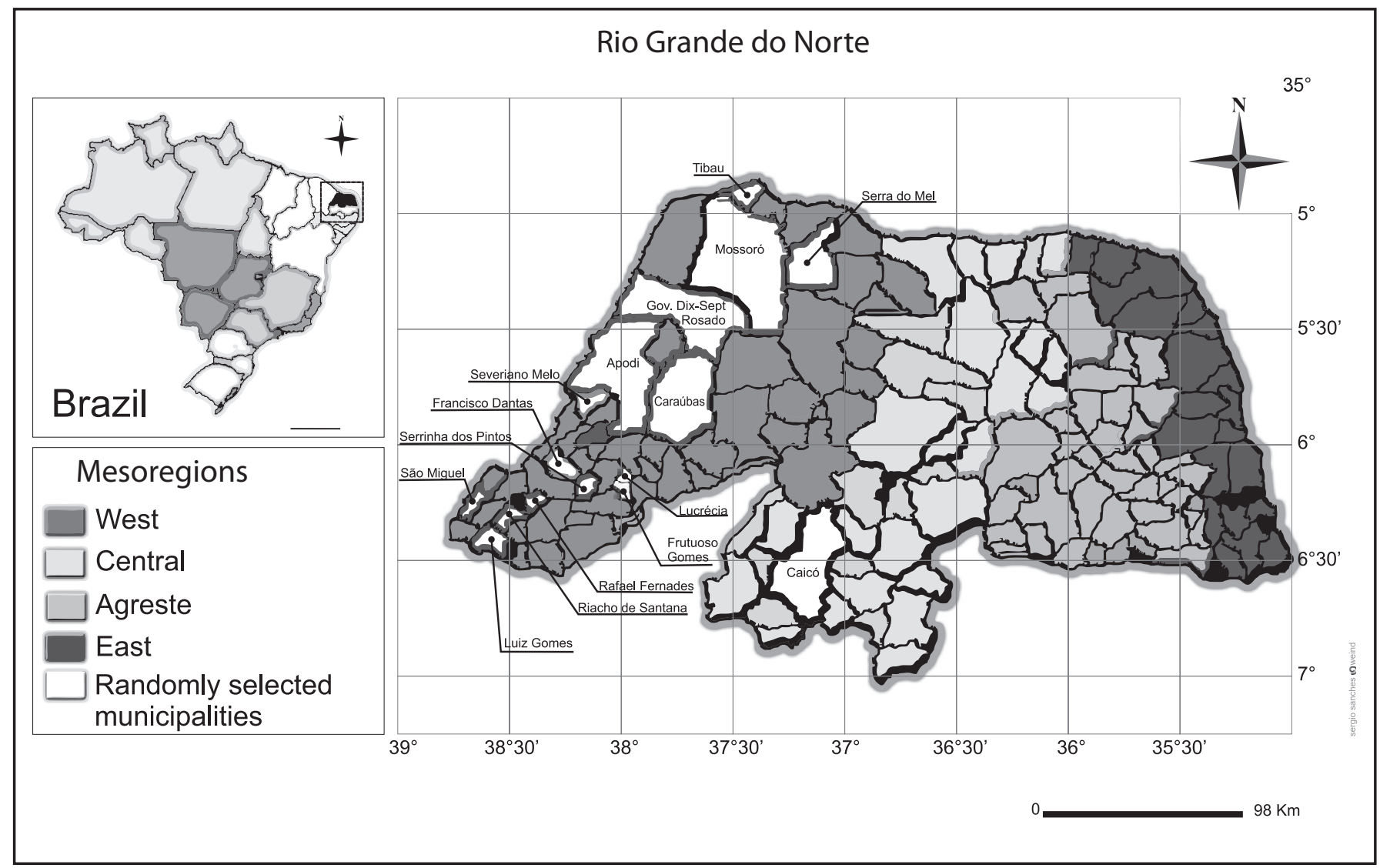

FIGURE 1 - Map of Rio Grande do Norte, Brazil, divided by mesoregions, with the municipalities evaluated in the seroepidemiological survey (2007-2009) in white. 
to the preliminary estimate ${ }^{15}$. The rural population involved totaled 6,960 individuals ${ }^{14}$.

Thus, calculation of sample size was determined by:

$$
n=\frac{N p(1-p)}{(N-1) D+p(1-p)}
$$

where, $\mathrm{n}=$ sample size, $\mathrm{N}=$ total number of residents, and $\mathrm{D}=\varepsilon^{2} / 4$, with $\varepsilon$ as a limit for an estimated error of $\mathrm{p}$, which satisfies $\mathrm{P}(|\mathrm{p}-\hat{p}|<\varepsilon)=0.95$, and $\hat{p}$ as the estimator of the proportion of individuals presenting positive serology in the west mesoregion or the municipality of Caicó.

Thus, considering the west mesoregion, $\varepsilon=0.015, \mathrm{~N}=77,204$, and substituting $\mathrm{p}$ for $\hat{p}=0.09$, the minimum sample size obtained was $\mathrm{n}=1,429$. For the municipality of Caicó, considering $\varepsilon=0.02$, $\mathrm{N}=6,960$, and substituting $\mathrm{p}$ for $\hat{p}=0.037$, the minimum sample size obtained was $\mathrm{n}=339$.

\section{Sample collection}

Following the randomized selection of the municipalities and calculation of minimum sample sizes, the rural communities were randomly selected. Between 2007 and 2009, blood samples were collected by venipuncture from 1,950 individuals resident in the west mesoregion and 390 individuals from the municipality of Caicó, between 7 and 90 years of age, of both sexes. The sera were separated by centrifugation at $2,500 \mathrm{rpm}$ for $10 \mathrm{~min}$ at room temperature (Centrifuge Fanem Excelsa ${ }^{\circledR}$, model 206, São Paulo, Brazil), aliquoted, and stored at $20^{\circ} \mathrm{C}$ until use. A questionnaire developed specifically for the study was validated ${ }^{15}$ and used to collect data from participants to identify epidemiological variables for risk of infection, such as sex, age, birthplace, education, knowledge of triatomines, the presence of triatomines inside the domicile, blood transfusion, and the length of time the individual had resided in the rural or urban zone.

\section{Seroprevalence}

Detection of anti-T. cruzi antibodies was performed using the following: Chagatest ${ }^{\circledR}$ recombinant ELISA v. 3.0 kit, with sensitivity of $98.8 \%$ and specificity of $99.6 \%{ }^{16}$; Chagatest ${ }^{\circledR}$ hemmaglutination inhibition (HAI), screening A-V kit (Wiener Lab ${ }^{\circledR}$, Rosário, Argentina), with sensitivity of $100 \%$ and specificity of $98.7 \%{ }^{16}$, according to the manufacturer, with titers of $1: 40$ considered the cutoff point for this method; and indirect immunofluorescence (IIF), using as antigen the epimastigotes of T. cruzi Y strain maintained in culture and fixed with $20 \%$ formaldehyde. Anti-human IgG immunoglobulin labeled with fluorescein isothiocyanate (Sigma Chemical Company ${ }^{\circledR}$, Missouri, USA) was used as conjugate, with titers of $1: 40$ considered the cutoff point ${ }^{17}$. The result for each serum was considered positive for infection by $T$. cruzi when two methods with different principles were reactive, indeterminate when only one method was reactive, and negative when these methods were nonreactive, in accordance with the recommendations of the World Health Organization ${ }^{18,19}$. In sera presenting indeterminate results, the Western blot test (TESAcruzi, bioMérieux Brazil) was performed to confirm anti-T. cruzi reactivity ${ }^{20}$.

\section{Statistical analysis}

The database containing demographic and socio-environmental variables was analyzed using the software Excel and the Statistical Package for the Social Sciences (SPSS), version 17. Descriptive analysis, the Chi-square test for association, multivariate analysis of clusters, and the comparison test of proportions were performed. The results were considered significant when the $\mathrm{p}$ value was less than $0.05(\mathrm{p}<0.05)$.

\section{Ethical considerations}

The ethical principles in the guidelines of resolution 196/96 of the Brazilian National Health Council (Conselho Nacional de Saúde) concerning research involving human subjects were complied with in this work. Rural residents 7 years of age or over and of both sexes were freely and spontaneously invited to participate in the survey and were included after signing a term of free, informed consent (Comitê de Ética em Pesquisa da Universidade Federal de Minas Gerais - COEP/UFMG No.312.2006). In the case of minors, parents or guardians signed the term of consent. All seropositive individuals were referred for clinical follow-up with the closest Family Health Strategy (FHS) team.

\section{RESULTS}

From 2007 to $2009,2,340$ individuals from 16 municipalities in $\mathrm{RN}$ were investigated, 15 from the west mesoregion and one from the central mesoregion. The estimated seroprevalence for T. cruzi infection was $6.5 \%(126 / 1950)$ positivity for the west mesoregion, corresponding to 14,151 individuals currently infected, based on data from the last census for the rural population in this mesoregion ${ }^{12}$. In the municipality of Caicó, seroprevalence was 3.3\% (13/390), corresponding to 175 individuals currently infected, also based on the last census for the rural population in this municipality ${ }^{12}$ (Figure 2 and Table 1).

The mean age of the entire population was 38 years, with a median of 37 years [standard deviation $(\mathrm{SD})=19$ years; range, 7 to 90 years). For seropositive individuals from the west mesoregion, the mean age was 48 years, with a median of 50 years (SD = 14 years; range, 18 to 84 years). Among the individuals from the municipality of Caicó, the mean age was 47 years, with a median of 43 years ( $\mathrm{SD}=13$ years; range, 22 to 70 years). Seropositivity rose progressively with age up to 50 years in the west mesoregion $(\mathrm{p}<0.001)$ and up to 40 years in the municipality of Caicó, decreasing thereafter in both groups; however, no evidence of association with age was observed $(\mathrm{p}=0.401)$. No seropositive individuals under the age of 18 years were registered. Regarding sex, no evidence of an association with seropositivity was observed ( $p=0.107$ for the west mesoregion, $\mathrm{p}=0.880$ for Caicó).

Cluster analysis of the west mesoregion municipalities according to seropositivity revealed the existence of three groups of prevalence in this area: the first involving those with the lowest prevalence, between $0 \%$ and $2.4 \%$; the second with prevalence ranging from $2.5 \%$ to $4.9 \%$, represented by Mossoró, São Miguel, and Riacho de Santana; and the third with higher prevalence rates between $8 \%$ and $10.4 \%$, represented by Apodi, Caraúbas, Gov. Dix-Sept Rosado, Lucrécia, and Severiano Melo, confirming significant differences between groups $(\mathrm{p}<0.001)$.

The epidemiological variables related to the risk of acquiring T. cruzi infection were investigated. In relation to education, the majority of seropositive individuals had not completed primary 
school, although a significant association with prevalence was only verified for the west mesoregion (Table 2). Regarding knowledge of the triatomine, evidence of an association with seropositivity was verified for the west mesoregion $(p=0.007)$, but was not observed for the municipality of Caicó $(\mathrm{p}=0.407)$. The remaining variables, such as the presence of triatomines inside the domicile, individuals who received blood transfusions, and length of residence in the rural or urban zone, showed no evidence of an association with seropositivity in any of the areas studied (Table 2).

TABLE 1 - Anti-Trypanosoma cruzi seropositivity among rural zone residents of the west mesoregion and the municipality of Caicó, State of Rio Grande do Norte, Brazil, from 2007 to 2009

\begin{tabular}{|c|c|c|c|c|c|}
\hline \multirow[b]{2}{*}{ Municipalities } & \multicolumn{2}{|c|}{ Positive } & \multicolumn{2}{|c|}{ Negative } & \multirow{2}{*}{$\begin{array}{r}\text { Tota } \\
\mathbf{n}\end{array}$} \\
\hline & $\mathbf{n}$ & $\%$ & $\mathbf{n}$ & $\%$ & \\
\hline Apodi & 31 & 9.3 & 304 & 90.7 & 335 \\
\hline Caraúbas & 49 & 10.3 & 429 & 89.7 & 478 \\
\hline Francisco Dantas & 0 & 0.0 & 36 & 100.0 & 36 \\
\hline Frutuoso Gomes & 0 & 0.0 & 94 & 100.0 & 94 \\
\hline Gov. Dix-Sept Rosado & 9 & 8.0 & 103 & 92.0 & 112 \\
\hline Lucrécia & 3 & 8.8 & 31 & 91.2 & 34 \\
\hline Luís Gomes & 0 & 0.0 & 84 & 100.0 & 84 \\
\hline Mossoró & 10 & 3.7 & 258 & 96.3 & 268 \\
\hline Rafael Fernandes & 0 & 0.0 & 48 & 100.0 & 48 \\
\hline Riacho de Santana & 3 & 4.9 & 58 & 95.1 & 61 \\
\hline São Miguel & 4 & 2.5 & 159 & 97.5 & 163 \\
\hline Serra do Mel & 0 & 0.0 & 19 & 100.0 & 19 \\
\hline Serrinha dos Pintos & 0 & 0.0 & 46 & 100.0 & 46 \\
\hline Severiano Melo & 17 & 10.4 & 146 & 89.6 & 163 \\
\hline Tibau & 0 & 0.0 & 09 & 100.0 & 09 \\
\hline Total & 126 & 6.5 & 1,824 & 93.5 & 1,950 \\
\hline Caicó & 13 & 3.3 & 377 & 96.7 & 390 \\
\hline
\end{tabular}

n: number of individuals; Gov. Dix-Sept Rosado: Governador Dix-Sept Rosado.

TABLE 2 - Anti-Trypanosoma cruzi seropositivity among rural zone residents of the west mesoregion and the municipality of Caicó, State of Rio Grande do Norte, Brazil, in relation to the epidemiological variables.

\begin{tabular}{|c|c|c|c|c|c|c|c|}
\hline \multirow[b]{2}{*}{ Variables } & & \multicolumn{3}{|c|}{ West mesoregion } & \multicolumn{3}{|c|}{ Municipality of Caicó } \\
\hline & & $\mathbf{n}$ & $\%$ & p value & $\mathbf{n}$ & $\%$ & p value \\
\hline \multirow[t]{7}{*}{ Educational level } & $\mathrm{IL}$ & 21 & 16.7 & 0.022 & 4 & 30.8 & 0.609 \\
\hline & PMI & 80 & 63.5 & & 7 & 53.8 & \\
\hline & PMC & 2 & 1.6 & & 0 & 0.0 & \\
\hline & HSI & 6 & 4.8 & & 0 & 0.0 & \\
\hline & HSC & 10 & 7.9 & & 2 & 15.4 & \\
\hline & CUI & 0 & 0.0 & & 0 & 0.0 & \\
\hline & CUC & 7 & 5.5 & & 0 & 0.0 & \\
\hline \multirow[t]{2}{*}{ Knowledge of the triatomine } & Yes & 116 & 92.1 & 0.007 & 13 & 100.0 & 0.407 \\
\hline & No & 10 & 7.9 & & 0 & 0.0 & \\
\hline \multirow[t]{2}{*}{ Triatomines inside the domicile } & Yes & 65 & 51.6 & 0.439 & 11 & 84.6 & 0.399 \\
\hline & No & 61 & 48.4 & & 2 & 15.4 & \\
\hline \multirow[t]{2}{*}{ Blood transfusion } & Yes & 4 & 3.2 & 0.819 & 0 & 0.0 & 0.242 \\
\hline & No & 122 & 96.8 & & 13 & 100.0 & \\
\hline \multirow[t]{2}{*}{ Zone of longest residential duration } & Urban & 3 & 2.4 & 0.071 & 0 & 0.0 & 0.383 \\
\hline & Rural & 123 & 97.6 & & 13 & 100.0 & \\
\hline
\end{tabular}

n: number of individuals; IL: illiterate; PMI: primary/middle school incomplete; PMC: primary/middle school complete; HSI: high school incomplete; HSC: high school complete; CUI: college/university incomplete; CUC: college/university complete. 

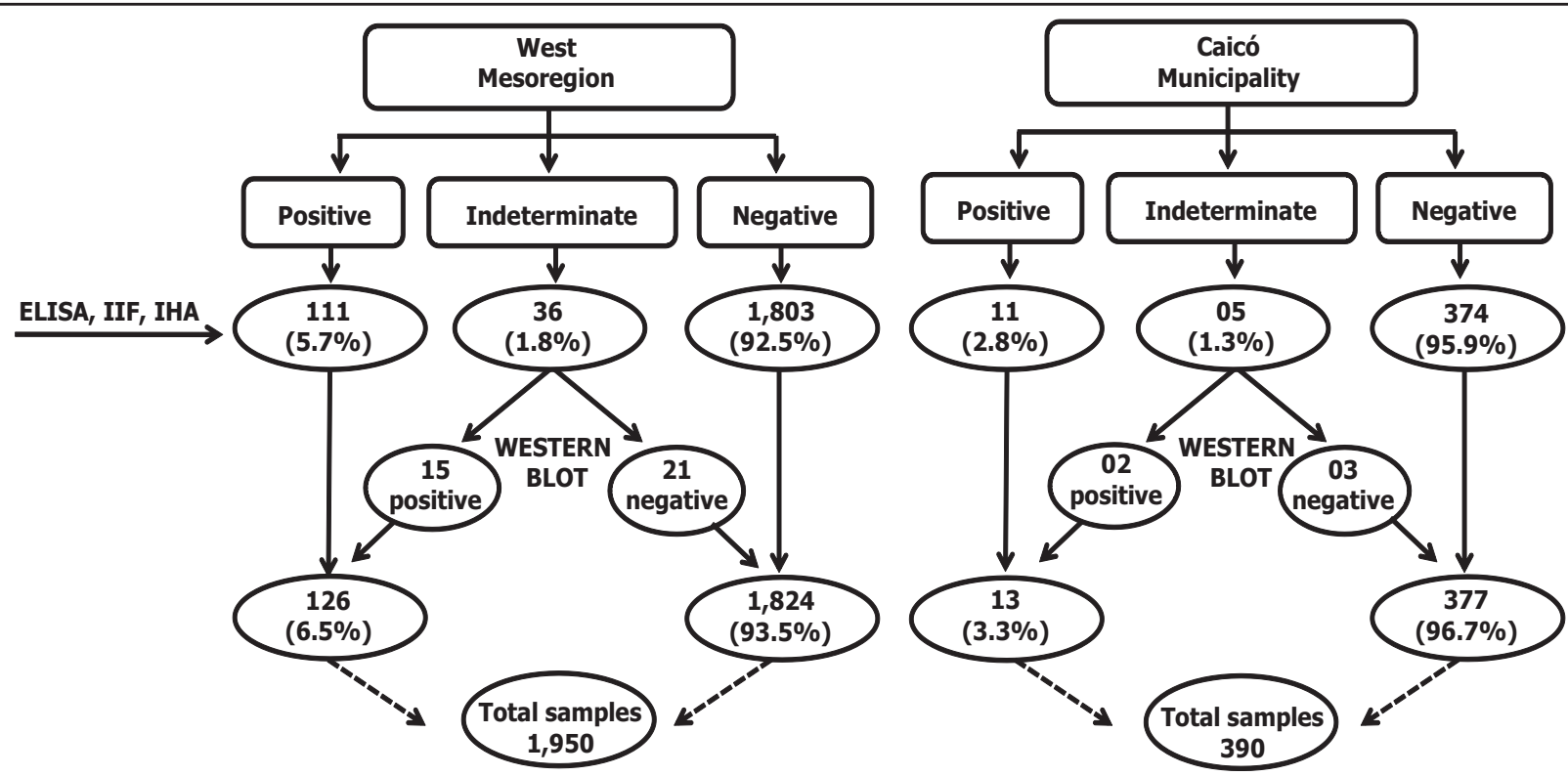

FIGURE 2 - Fluxogram of anti-Trypanosoma cruzi serum reactivity among rural zone residents of the west mesoregion and Caicó municipality, State of Rio Grande do Norte, Brazil, (2007-2009) by ELISA (enzyme-linked immunosorbent assay), IIF (indirect immunofluorescence), IHA (indirect hemagglutination), and indeterminate samples confirmed by western blot.

\section{DISCUSSION}

American trypanosomiasis or Chagas disease is an endemic infection, with an essentially chronic evolution caused by the etiological agent, the protozoan T. cruzi $^{1}$, and results in a long association between the host and the parasite. Currently, there remain rural populations residing in environments where the vectors of the parasite can be found in both the peridomicile and intradomicile spaces, in different geographical regions in several Latin American countries, including Brazil.

The prevalence of T. cruzi infection determined in this study was $6.5 \%$ for the west mesoregion and $3.3 \%$ for the municipality of Caicó, exceeding the rates obtained in the first national survey ${ }^{5}$ and highlighting a state with present and future problems, since even following the implementation of control measures directed at the vector throughout the Brazilian territory, these prevalence rates remain high.

The literature reports wide variability in seroprevalence rates for T. cruzi in different states of the Northeastern region ${ }^{21-24}$, ratifying the importance of surveys that demonstrate the current epidemiological situation of this infection. The lower percentage of positivity determined for Caicó compared with the west mesoregion can be attributed to the fact that vector control campaigns, initiated in $\mathrm{RN}$ around 1972, were more organized in the central mesoregion where this municipality is situated and remain so to this day. The fact that this municipality houses one of two regional headquarters of the National Health Foundation (Fundação Nacional de Saúde, FUNASA) that exist in the state also contributes to greater control in this region. On the other hand, the greater prevalence in the west mesoregion could be related to the fact that of the 115 municipalities in an area considered endemic for Chagas disease in $\mathrm{RN}$, where control actions are discontinuous due to lack of human resources, supplies and insecticides ${ }^{11}$, only 12 municipalities have consolidated the phase of entomological surveillance. Allied to this, predominant vectors, such as Tr. brasiliensis and Tr.pseudomaculata, remain endemic and difficult to control and are a major operational challenge ${ }^{6}$. These vectors, particularly $T r$. brasiliensis, although not domiciled, are capable of maintaining the parasite transmission cycle among the rural population.

The last national serological survey warned that active transmission of T. cruzi could be occurring in RN, based on the case of a seropositive child and his/her seronegative mother. The data reveal, however, that this finding could be even higher, since the number of samples tested corresponded to $55.4 \%$ of those referred for collection ${ }^{8}$, confirming the need for surveys based on primary and/or secondary data that clarify the current epidemiological situation of this infection.

Regarding age, seropositive individuals presented a higher mean age than the general population, suggesting a direct relation between prevalence and advancing age. In fact, this behavior is expected, since due to the interruption of T. cruzi vectorial transmission, contact with vectors among these individuals occurred no later than the 1980s, when the program to control Chagas disease was prioritized by the Ministry of Health. Similar findings were also reported in other studies in Brazil, in the States of Mato Grosso do Sul, Minas Gerais, Piauí, and São Paulo ${ }^{23,25-29}$.

This survey detected no association between seroprevalence for T. cruzi infection and sex, in agreement with similar studies ${ }^{25,26,29-32}$. Of the 126 seropositive individuals in the west mesoregion, 62 were female and 64 were male. In Caicó, seven of the 13 seropositive individuals were female and six were male. Few studies have reported sex as a variable that interferes in the behavior of parasite vector transmission, given the equiprobability of acquiring the infection for both sexes in the home environment ${ }^{32}$. However, certain studies report an association between these variables, with a predilection for females ${ }^{28}$, or related to the professional activity of the individual ${ }^{33}$, raising questions regarding sex and susceptibility to infection by T. cruzi.

The profile of seropositive individuals regarding education level revealed a predominance of individuals with low levels of education, 
suggesting that infection is closely related to the development of the population, generally affecting the poorest individuals and those with less education. Several authors have reported similar findings ${ }^{6,26,32,34}$, including one study characterizing illiteracy as the principal social marker of Chagas infection ${ }^{23}$.

The large number of seropositive individuals with prior knowledge and contact with triatomines suggests that the main means of infection in this area is vectorial, supported by the fact that there was no evidence of association with blood transfusion, which highlights the importance of continuous entomological surveillance. In the latest survey concerning Chagas disease, intradomicile presence of the triatomine presented a threshold value for significance ${ }^{8}$, while the present study determined no evidence of an association.

The percentage of samples initially considered indeterminate in this survey can be explained by the variability among T. cruzi isolates associated with immunogenetic factors of the human host, which can influence the performance of serological assays ${ }^{35}$, since the parasite presents wide genetic diversity ${ }^{36}$. Other factors involve the range of antigens activated during the host immune response. These modifications also involve morphological changes in the biological cycle, which involve numerous antigens in different phases ${ }^{37}$. T. cruzi can also produce several variants of surface proteins that prevent certain antibodies from binding to the parasite ${ }^{38}$. Moreover, it is possible that cross-reactions with anti-Leishmania antibodies may occur, which can be minimized with the use of enzyme-linked immunoabsorbent assay (ELISA) with recombinant antigens, improving the specificity of the assay ${ }^{39}$. Another valid hypothesis is that these indeterminate cases could be associated with the presence of different T. cruzi genotypes in the mesoregions evaluated ${ }^{40}$, suggesting that differences in seropositivity could be related to the genotype of the parasite.

Despite the considerable problems related to its control, Chagas disease is a low political priority in Brazil, principally because it has a long clinical evolution and its social repercussion is very low among populations at risk ${ }^{41}$. Clearly the definitive solution of T. cruzi transmission depends on improving the living conditions of much of the population, particularly in rural areas, but it is equally certain that sufficient accumulated techniques exist to prevent new cases of the disease $\mathrm{e}^{42}$. Further improvement requires the consolidation of policies that recognize the need for periodic surveys to generate information that cannot be obtained from continuous records and that are essential for planning and the evaluation of policies to promote health and for the prevention and control of disease $\mathrm{e}^{43}$.

Considering the data obtained in this study, analysis verified that the prevalence of human infection by T. cruzi remains high. It is concentrated in some municipalities in the central area of the west mesoregion and continues to be an important public health problem for the State of Rio Grande do Norte. However, the decline of vector transmission in this mesoregion and Caicó highlights the effectiveness of control measures in the prevention of Chagas disease in this population, promoting a better quality of life for many individuals. The epidemiological variables assessed do not appear to influence seropositivity, with the exception of educational level and knowledge regarding the triatomine among seroreactive individuals in the west mesoregion. Further studies are being conducted in the areas involved to assess the clinical evolution of seroreactive individuals, as well as the immunological profile and morbidities associated with T. cruzi infection.

\section{ACKNOWLEDGMENTS}

The authors thank the Secretariat of State for Public Health of Rio Grande do Norte, represented by the health authorities and agents of the Municipal Secretaries of the west and central mesoregions for their indispensable support for the field activities during the development of this survey. The authors are also grateful to Philip S.P. Badiz for his critical reading and revision of the manuscript.

\section{CONFLICT OF INTEREST}

The authors declare that there is no conflict of interest.

\section{FINANCIAL SUPPORT}

Dr L.M.C.G, reseacher, has a scholarship (Desenvolvimento Científico e Tecnológico Regional/Conselho Nacional de Desenvolvimento Científico e Tecnológico/Fundação de Apoio à Pesquisa do Estado do Rio Grande do Norte; DCR/CNPq/FAPERN), research grant DCR/CNPq/FAPERN, Accord n 68.0025/2005/7. MCT/CNPq n 14/2010-Universal; MCT/CNPq/CT-Saúde/MS/SCTIE/DECIT N³4/2008 and PPSUS/FAPERN/ PROJ-430-19969656.

\section{REFERENCES}

1. Chagas CRJ. Nova tripanozomiase humana: estudos sobre a morfolojia e o ciclo evolutivo do Schizotrypanum cruzi n. gen., n. sp., ajente etiolojico de nova entidade morbida do homem. Mem Inst Oswaldo Cruz 1909; 1:159-218.

2. Organización Panamericana de la Salud. Estimación cuantitativa de la enfermedad de Chagas en las Américas. OPS/HDM/CD/425-06; 2006.

3. World Health Organization. Chagas disease (American trypanosomiasis) [Internet]. Genebra: World Health Organization; 2010. [cited 2010June]. Available from: http://www.who.int/ mediacentre/factsheets/fs340/en/index.html.

4. Moncayo A, Silveira AC. Current epidemiological trends for Chagas disease in Latin America and future challenges in epidemiology, surveillance and health policy. Mem Inst Oswaldo Cruz 2009; 104 (supl I):17-30.

5. Camargo ME, Silva GR, Castilho EA, Silveira AC. Inquérito sorológico da prevalência de infecção chagásica no Brasil, 1975/1980. Rev Inst Med Trop Sao Paulo 1984; 26:192-204.

6. Dias JC, Machado EMM, Fernandes AL, Vinhaes MC. Esboço geral e perspectivas da doença de Chagas no Nordeste do Brasil. Cad Saude Publica 2000; 16 (supl II):13-34

7. Silveira AC, Vinhaes MC. Doença de Chagas: aspectos epidemiológicos e de controle. Rev Soc Bras Med Trop 1998; 31 (supl II):15-60.

8. Luquetti AO, Passos ADC, Silveira AC, Ferreira AW, Macedo V, Prata AR. O inquérito nacional de soroprevalência de avaliação do controle da doença de Chagas no Brasil (2001-2008). Rev Soc Bras Med Trop 2011; 44 (supl II):108-121.

9. AlencarJE. História Natural da doença de Chagas no Estado do Ceará. Fortaleza: Imprensa Universitária da Universidade Federal do Ceará; 1987.

10. Dias JCP, Coura JR. Epidemiologia. In: Dias JCP, Coura JR, editors. Clínica e Terapêutica da doença de Chagas. Um manual prático para o clínico geral. Rio de Janeiro: Editora FIOCRUZ; 1997. p. 33-66.

11. Ministério da Saúde. Fundação Nacional de Saúde (FUNASA). Coordenação Regional do Rio Grande do Norte. Projeto de Controle de Doenças Endêmicas no Nordeste. Rio Grande do Norte: FUNASA; 1996.

12. Instituto Brasileiro de Geografia e Estatística. Censo Demográfico de 2010 [Internet]. Rio de Janeiro: IBGE; 2010. [cited 2011 June 12]. Available from: http://www.censo2010.ibge.gov.br/resultados_do_censo2010.php/.

13. Instituto de Desenvolvimento Sustentável e Meio Ambiente do RN. Anuário Estatístico de 2008 [Internet]. Natal: IDEMA; 2008. [cited 2011 June 12]. Available from: http://www.idema.rn.gov.br/contentproducao/aplicacao/ idema/socio_economicos/arquivos/anuario2008/index.htm. 
14. Instituto Brasileiro de Geografia e Estatística. Censo Demográfico de 2000 [Internet]. Rio de Janeiro: IBGE; 2002. [cited 2011 June 12]. Available from: http://www.ibge.gov.br/home/estatistica/populacao/censo2000/.

15. Câmara ACJ. Variabilidade genética de amostras do Trypanosoma cruzi isoladas no semiárido potiguar, RN [Doctors thesis]. [Belo Horizonte]: Universidade Federal de Minas Gerais; 2008. 147 p.

16. Otani MM, Vinelli E, Kirchhoff LV, Pozo A, Sands A, Vercauteren G, et al. WHO comparative evaluation of serologic assays for Chagas disease. Transfusion 2009; 49:1076-1082.

17. Camargo ME. Fluorescent antibody test for the diagnosis of American trypanosomiasis. Technical modification employing preserved culture forms of Trypanosoma cruzi in a slide test. Rev Inst Med Trop Sao Paulo 1966; 8:227-234.

18. World Health Organization. Control of Chagas disease. Second report of the WHO Expert Committee. World Health Organization Technical Report Series 905; 2002.

19. Ministério da Saúde. Secretaria de Vigilância em Saúde. Consenso Brasileiro em doença de Chagas. Rev Soc Bras Med Trop 2005; 38 (supl III):1-29.

20. Umezawa ES, Nascimento MS, Kesper Jr N, Coura JR, Borges-Pereira J, Junqueira ACV, et al. Immunoblot assay using excreted-secreted antigens of Trypanosoma cruzi in serodiagnosis of congenital, acute, and chronic Chagas' disease. J Clin Microbiol 1996; 34:2143-2147.

21. Coura JR, Abreu LL, Dubois LEG, Lima FC, Arruda Jr E, Willcox HPF, et al. Morbidade da doença de Chagas. II-Estudos seccionais em quatro áreas de campo no Brasil. Mem Inst Oswaldo Cruz 1984; 79:101-124.

22. Borges-Pereira J, Castro JAF, Campos JHF, Nogueira JS, Zauza PL, Marques P, et al. Estudo da infecção e morbidade da doença de Chagas no município de João Costa - Parque Nacional Serra da Capivara, Piauí, Brasil. Rev Soc Bras Med Trop 2002; 35:315-322.

23. Borges-Pereira J, Castro JAF, Silva AG, Zauza PL, Bulhões TP, Gonçalves ME, et al. Soroprevalência da infecção chagásica no Estado do Piauí, 2002. Rev Soc Bras Med Trop 2006; 39:530-539.

24. Borges-Pereira J, Sarquis O, Zauza PL, Britto C, Lima MM. Epidemiologia da doença de Chagas em quatro localidades rurais de Jaguaruana, Estado do Ceará. Soroprevalência da infecção, parasitemia e aspectos clínicos. Rev Soc Bras Med Trop 2008; 41:345-351

25. Borges-Pereira J, Zauza PL, Galhardo MC, Nogueira JS, Pereira GROL, Cunha RV. Doença de Chagas na população urbana do distrito sanitário de Rio Verde, Mato Grosso do Sul, Brasil. Rev Soc Bras Med Trop 2001; 34:459-466.

26. Silva EM, Rocha MOC, Silva RC, Paixão GC, Buzzati H, Santos AN, et al. Estudo clínico-epidemiológico da doença de Chagas no distrito de Serra Azul, Mateus Leme, centro-oeste do Estado de Minas Gerais. Rev Soc Bras Med Trop 2010; 43:178-181.

27. Dias JCP, Machado EMM, Borges EC, Moreira EF, Gontijo C, Azeredo BVM. Doença de Chagas em Lassance, MG. Reavaliação clínico-epidemiológica 90 anos após a descoberta de Carlos Chagas. Rev Soc Bras Med Trop 2002; 35:167-176.

28. Montoya R, Dias JCP, Coura JR. Chagas disease in a community in southeast Brazil. I. A serological follow-up study on a vector controlled area. Rev Inst Med Trop Sao Paulo 2003; 45:269-274.
29. Carvalho ME, Latorre MRDO, Ferreira CS, Mello CS, Barata JMS Soroprevalência de infecção chagásica em área de Triatoma infestans após medidas de controle. Rev Saude Publica 2000; 34:15-20.

30. Carvalho ME, Silva RA, Barata JMS, Domingos MF, Ciaravolo RMC, Zacharias F. Soroepidemiologia da triponosomíase americana na região do litoral sul, São Paulo. Rev Saude Publica 2003; 37:49-58.

31. Rodríguez-Bonfante C, Amaro A, García M, Wohlert LEM, Guillen P, García RA, et al. Epidemiologia de la enfermedad de Chagas en el municipio Andrés Eloy Blanco, Lara, Venezuela: infestación triatomínica y seroprevalencia em humanos. Cad Saude Publica 2007; 23:1133-1140.

32. Godoy I, Meira DA. Soroprevalência da infecção chagásica em moradores de municípios da região de Botucatu, Estado de São Paulo. Rev Soc Bras Med Trop 2007; 40:516-520.

33. Coura JR, Willcox HPF, Arboleda-Naranjo M, Fernandes O, Paiva DD. Chagas' disease in the brazilian amazon. III. A cross-sectional study (1). Rev Inst Med Trop Sao Paulo 1995; 37:415-420.

34. Pompilio MA, Dorval MEMC, Cunha RV, Britto C, Borges-Pereira J. Aspectos epidemiológicos, clínicos e parasitológicos da doença de Chagas em mato Grosso do Sul. Rev Soc Bras Med Trop 2005; 38:473-478.

35. Luquetti AO, Ponce C, Ponce E, Esfandiari J, Schijman A, Revollo S, et al. Chagas' disease diagnosis: a multicentric evaluation of Chagas Stat-Pak, a rapid immunochromatographic assay with recombinant proteins of Trypanosoma cruzi. Diagn Microbiol Infect Dis 2003; 46:265-271.

36. Souto RP, Fernandes O, Macedo AM, Campbell DA, Zingales B. DNA markers define two major phylogenetic lineages of Trypanosoma cruzi. Mol Biochem Parasitol 1996; 83:141-152.

37. Macedo AM, Machado CR, Oliveira RP, Pena SDJ. Trypanosoma cruzi: genetic structure of populations and relevance of genetic variability to the pathogenesis of Chagas Disease. Mem Inst Oswaldo Cruz 2004; 99:1-12.

38. Toledo MJ, Bahia MT, Veloso VM, Carneiro CM, Machado-Coelho GL, Alves $\mathrm{CF}$, et al. Effects of specific treatment on parasitological and histopathological parameters in mice infected with different Trypanosoma cruzi clonal genotypes. J Antimicrob Chemother 2004; 53:1045-1053.

39. Silveira JF, Umezawa ES, Luquetti AO. Chagas disease: recombinant Trypanosoma cruzi antigens for serological diagnosis. Trends Parasitol 2001; 17:286-291.

40. Câmara ACJ, Varela-Freire AA, Valadares HMS, Macedo AM, D’Ávila DA, Machado CR, et al. Genetic analyses of Trypanosoma cruzi isolates from naturally infected triatomines and humans in northeastern Brazil. Acta Trop 2010; 115:205-211.

41. Dias JCP. Globalização, iniqüidade e doença de Chagas. Cad Saude Publica 2007; 23 (supl I):13-22.

42. Silveira AC. Situação do controle da transmissão vetorial da doença de Chagas nas Américas. Cad Saude Publica 2000; 16 (supl II):35-42.

43. Barros MBA. Inquéritos domiciliares de saúde: potencialidades e desafios. Rev Bras Epidemiol 2008; 11 (supl I):6-19. 